Wojciech Dziedziak

\title{
Metaaksjologia Konstytucji RP a nonkognitywizm (zarys zagadnień podstawowych)
}

1. W niniejszym opracowaniu zostanie podjęte zagadnienie metaaksjologii Konstytucji Rzeczypospolitej Polskiej, kognitywizmu i nonkognitywizmu¹. Najpierw trzeba jednak ustalić znaczenie podstawowych dla dalszych rozważań terminów. Przez metaaksjologię Konstytucji RP, najogólniej rzecz biorąc, rozumiem problematykę sposobu ugruntowania wartości. Gdy mówimy o metaaksjologii Konstytucji, podejmujemy rozważania na temat źródeł, podstaw i sposobu istnienia wartości. A chodzi o wartości najbardziej podstawowe, zasadnicze, fundamentalne.

Kognitywizm (łac. cognitio - 'poznawanie, poznanie'; cognoscere - 'poznawać, poznać' $)^{2}$ w szerokim znaczeniu to stanowisko filozoficzne i metodologiczne odwołujące się do kategorii prawdziwości. Stanowiska motywowane kognitywistycznie ${ }^{3}$ w filozofii, a w szczególności w etyce, wykazują zróżnicowanie. Jednak dla dalszych rozważań istotne jest to, że kognitywizm przyjmuje, iż oceny, normy i wartości mają właściwości poznawcze. Wartości są zatem poznawalne. Kognitywizm przypisuje sądom moralnym wartość logiczną.

Natomiast nonkognitywizm, akognitywizm, antykognitywizm (ang. non-cognitivism) to stanowisko ${ }^{4}$ będące opozycją do kognitywizmu ${ }^{5}$ - zgodnie z nim wypowiedzi inne niż zdania, w tym zwłaszcza oceny i normy, nie mają wartości poznawczej,

1 Niniejsze opracowanie, przede wszystkim z uwagi na jego ramy, nie stanowi, rzecz jasna, całościowego, wyczerpującego ujęcia zagadnienia. Przedstawia tylko kwestie najbardziej zasadnicze.

2 M. Plezia (red.), Słownik łacińsko-polski, t. I, Warszawa 2007, s. 555 i 557.

3 Współcześnie rozwijane są także tzw. nauki kognitywne, koncentrujące swe badania nad umysłem ludzkim. Zalicza się do nich zwłaszcza psychologię kognitywną, filozofię umysłu, antropologię kognitywną, językoznawstwo kognitywne, neuronaukę. Jeśli chodzi o psychologię kognitywną (cognitive psychology), bada ona procesy poznawcze, takie jak m.in.: percepcja, pamięć, myślenie.

4 Protoplastą nonkognitywizmu w etyce był Dawid Hume, który twierdził, że moralność jest sprawą uczuć, a nie rozumu. Autor Traktatu o naturze ludzkiej sformułował tezę o niemożliwości logicznego przejścia od zdań o faktach (jest) do zdań o wartościach i powinnościach. Nie ma bowiem racjonalnego przejścia od empirycznego ,jest” do moralnego „powinien”. A w związku z tym żadna norma nie jest racjonalnie (logicznie) „wywodliwa” (wyprowadzalna) z twierdzeń opisujących rzeczywistość.

5 W etyce dominującym stanowiskiem nonkognitywistycznym jest emotywizm, będący mocną postacią subiektywizmu etycznego. Jeden z jego głównych przedstawicieli, Alfred 
nie są ani prawdziwe, ani fałszywe (nie mają wartości logicznej) ${ }^{6}$. Akognitywizm zakłada, że kwestie moralne, wartości nie podlegają kwalifikacji poznawczej. Tak więc człowiek nie jest w stanie poznać tego, co dobre czy moralnie powinne.

Zastanówmy się, jakie metaaksjologiczne rozstrzygnięcia odnajdujemy w Konstytucji RP. Konstytucja we wstępie ${ }^{7}$ przyjmuje istnienie uniwersalnych wartości, są nimi: prawda, sprawiedliwość, dobro i piękno. Zacytujmy słowa rozpoczynające Konstytucję:

W trosce o byt i przyszłość naszej Ojczyzny, odzyskawszy w 1989 roku możliwość suwerennego i demokratycznego stanowienia o Jej losie, my, Naród Polski - wszyscy obywatele Rzeczypospolitej, zarówno wierzący w Boga będącego źródłem prawdy, sprawiedliwości, dobra i piękna, jak i nie podzielający tej wiary, a te uniwersalne wartości wywodzący z innych źródeł [...].

Jules Ayer, przyjmował, że wypowiedzi oceniające nie pełnią funkcji poznawczej i wyrażają jedynie emocje (indywidualnie przeżywane emocje aprobaty i dezaprobaty) oraz nastawienia. Emotywizm zyskał liczne grono zwolenników zarówno wśród filozofów, jak też teoretyków i filozofów prawa.

6 Por. A. Kozak, Antykognitywizm, [w:] A. Bator (red.), Wprowadzenie do nauk prawnych. Leksykon tematyczny, Warszawa 2008, s. 17.

7 Szerzej o prawnej doniosłości wstępu do konstytucji por. M. Stefaniuk, Preambuła aktu normatywnego $w$ doktrynie oraz $w$ procesie stanowienia $i$ stosowania polskiego prawa $w$ latach 1989-2007, Lublin 2009, s. 63-78. Por. także: L. Garlicki, Wstęp (pkt 3), [w:] idem (red.), Konstytucja Rzeczypospolitej Polskiej. Komentarz, t. V, Warszawa 2007. Jak podkreśla M. Piechowiak: „Naturalnym miejscem wskazania fundamentów aksjologicznych jest wstęp, który w pewien sposób «konstytucjonalizuje konstytucję», nie tylko w aspekcie prawnym, lecz także w kontekście kultury, w której funkcjonuje oparty na konstytucji system prawny" - M. Piechowiak, Aksjologiczne podstawy polskiego prawa, [w:] T. Guz, J. Głuchowski, M. R. Pałubska (red.), Prawo polskie. Próba syntezy, Warszawa 2009, s. 85. Również w doktrynie prawa konstytucyjnego przyjmuje się, że preambuła do konstytucji ma charakter normatywny (takie stanowisko jest dominujące). Przykładem niech będzie konstatacja K. Complaka: „Odszedł bezpowrotnie w przeszłość pogląd [...], że treść wstępu do konstytucji «ma jedynie znaczenie filozoficzne»" - K. Complak, Preambuła, [w:] J. Boć (red.), Konstytucje Rzeczypospolitej oraz komentarz do Konstytucji RP z 1997 roku, Wrocław 1998, s. 12. Na konieczność uwzględniania rozstrzygnięć aksjologicznych przyjętych we wstępie do Konstytucji RP z 1997 r. wskazywał niejednokrotnie także Trybunał Konstytucyjny, np.: „Nawet bowiem nienaganne z punktu widzenia techniki legislacyjnej stanowienie norm nie wyczerpuje istoty państwa prawnego. Normy te muszą realizować podstawowe założenia leżące u podstaw porządku konstytucyjnego w Polsce oraz realizować i strzec tego zespołu wartości, który konstytucja wyraża. W konsekwencji nie sposób ocenić zachowania zasad państwa prawnego bez uwzględnienia wartości wskazanych we wstępie do Konstytucji oraz z pominięciem sprecyzowanej w art. 1 Konstytucji zasady, że Polska jest dobrem wspólnym wszystkich obywateli" - wyrok TK z dnia 12 kwietnia 2000 r. (K8/98, OTK ZU 2000, nr 3, poz. 87). Por. także: wyrok TK z dnia 11 maja 2005 r. (K 18/04, OTK ZU 2005, Ser. A, nr 5, poz. 49), wyrok TK z dnia 3 listopada 2006 r. (K 31/06, OTK ZU 2006, Ser. A, nr 10, poz. 147). Jedną z fundamentalnych zasad polskiego porządku prawnego jest zasada pomocniczości, wyrażona tylko we wstępie do Konstytucji, a jej naruszenie traktowane jest w orzecznictwie $\mathrm{w}$ kategoriach naruszenia prawa. Zasada ta powoływana jest nie tylko w orzecznictwie Trybunału Konstytucyjnego, lecz także Sądu Najwyższego i Naczelnego Sądu Administracyjnego. 
Tak więc Konstytucja odwołuje się do istnienia $\mathrm{Boga}^{8}$, „[...] będącego źródłem prawdy, sprawiedliwości, dobra i piękna"9. W preambule jest też mowa o „poczuciu odpowiedzialności przed Bogiem lub przed własnym sumieniem" ustanawiających Konstytucję ${ }^{10}$. Już te sformułowania Konstytucji wskazują na odejście jej twórców od inspiracji woluntarystycznych, czysto pozytywistycznych ${ }^{11}$.

W Konstytucji nawiązano do ponadczasowych wartości, bowiem od starożytności prawda, dobro i piękno należą do kanonu podstawowych doskonałości ${ }^{12}$. Można powiedzieć, że kultura europejska została oparta na tych trzech uniwersalnych wartościach. Przez wieki ,utrzymywały” się one w europejskiej myśli jako najwyższe ${ }^{13}$. W filozofii średniowiecznej: verum, bonum, pulchrum występowały jako tzw. transcendentalia ${ }^{14}$. Pomiędzy nimi w Konstytucji znalazła się

8 Odwołania do Boga mają miejsce zarówno w historycznych, jak i współczesnych konstytucjach niektórych państw. Por. Konstytucję 3 maja z 1791 r., Konstytucję marcową z 1921 r., por. także np. Konstytucję Irlandii z 1937 r., Konstytucję Grecji z 1975 r., Konstytucję Szwajcarii z 1999 r., Ustawę zasadniczą RFN z 1949 r.

9 Twórcy Konstytucji uznali prawa ludzi wierzących, traktujących Boga jako rzeczywiste źródło uniwersalnych wartości. Jak podkreśla L. Garlicki, chodzi tutaj o „wskazanie fundamentalnego znaczenia tych wartości i przydanie im także normatywnego charakteru” - L. Garlicki, Wstęp (pkt 10), [w:] idem (red.), Konstytucja Rzeczypospolitej Polskiej...

${ }^{10} \mathrm{~W}$ literaturze zwraca się uwagę, że sformułowanie to nie jest poprawne. Z funktora „lub” wynika, że ludzie wierzący mają poczucie odpowiedzialności tyko przed Bogiem, a niewierzący mają poczucie odpowiedzialności tylko przez własnym sumieniem. Jak pisze J. Krukowski: „Należy jednak logicznie przyjąć, iż funktor «lub» spełnia tu funkcję łącznika, a nie rozłącznika. Ludzie wierzący mają bowiem poczucie odpowiedzialności przed Bogiem i przed własnym sumieniem" - J. Krukowski, Konstytucyjny system relacji między państwem a Kościołem katolickim oraz innymi kościołami i zwiqzkami wyznaniowymi, [w:] R. Mojak (red.), Ustrój konstytucyjny Rzeczypospolitej Polskiej, t. X, Lublin 2000, s. 109. Por. także M. Stefaniuk, op. cit., s. 283.

${ }^{11} \mathrm{~W}$ odniesieniu do wskazanych postanowień wstępu do Konstytucji L. Garlicki pisze: „,...] sformułowania te wskazują na wolę powiązania konstytucji z systemem norm i wartości wyższych (naturalnych), więc stojących poza (i ponad) unormowaniem pozytywnym i wyznaczających sposób pojmowania i stosowania przepisów konstytucyjnych" - L. Garlicki, Wstęp (pkt 10), [w:] idem (red.), Konstytucja Rzeczypospolitej Polskiej...

${ }^{12}$ Prawda, dobro i piękno pojawiają się zarówno w filozofii Platona, jak i Arystotelesa. Dla Platona należą one do świata idei niezmiennych i wiecznych. Najwyższą ideą była idea dobra (albo dobra, które jest jednocześnie pięknem). Dla Arystotelesa wartości te wyznaczają cele trzech dziedzin poznania. W Metafizyce czytamy, iż: „wszelka myśl jest albo praktyczna, albo wytwórcza, albo badawcza" - Arystoteles, Metafizyka, 1025b. Chodzi zatem o poznanie teoretyczne, praktyczne i wytwórcze (,pojetyczne”). Warto również zacytować pierwsze zdanie Etyki nikomachejskiej: „Wszelka sztuka i wszelkie badanie, a podobnie też wszelkie zarówno działanie, jak i postanowienie zdają się zdążać do jakiegoś dobra i dlatego trafnie określono dobro jako cel wszelkiego dążenia" - Arystoteles, Etyka nikomachejska, 1094a.

${ }^{13}$ Por. W. Tatarkiewicz, Dzieje sześciu pojęć. Sztuka, piękno, forma, twórczość, odtwórczość, przeżycia estetyczne, Warszawa 1988, s. 9.

${ }^{14}$ Transcendentalia (od łac. transcendere - 'przekraczać, wykraczać poza, przewyższać') to powszechne i konieczne właściwości tego, co realnie istnieje (bytów). Szerzej: A. Maryniarczyk, Transcendentalia, [w:] Powszechna encyklopedia filozofii, t. 9, Lublin 2008, s. 533, 535, 540-542. 
sprawiedliwość. Można zastanawiać się, dlaczego. Jej pojawienie się jest w pełni uzasadnione, gdyż sprawiedliwość jest konieczną zasadą życia społecznego. Warto przypomnieć znaną myśl Johna Rawlsa:

Jak prawda w systemach wiedzy, tak sprawiedliwość jest pierwszą cnotą społecznych instytucji. Teorię nieprawdziwą, choćby nawet wielce ekonomiczną i elegancką, trzeba odrzucić albo zrewidować; podobnie prawa i społeczne instytucje, nieważne jak sprawne i dobrze zorganizowane, muszą zostać zreformowane bądź zniesione, jeśli są niesprawiedliwe ${ }^{15}$.

Przypomnijmy, że te uniwersalne wartości w myśl Konstytucji wywodzone są z istoty Boga lub „z innych źródeł”. Jak podkreśla Leszek Garlicki: „«zarówno wierzący w Boga [...], jak i nie podzielający tej wiary» [...] wszyscy oni złączeni są (powinni być) wspólną akceptacją najbardziej uniwersalnych wartości: prawdy, sprawiedliwości, dobra i piękna"16. I, co istotne, Konstytucja nie mówi o wartościach powszechnie uznawanych, uważanych czy też uznanych za uniwersalne, ale wprost o wartościach uniwersalnych i tym samym potwierdza ich istnienie. Trybunał Konstytucyjny w wyroku z 11 maja 2005 r. (K 18/04) określił je mianem ,uniwersalnych wartości konstytucyjnych”.

Co należy rozumieć przez wartości uniwersalne? Słowo „uniwersalne”, zgodnie z jego słownikowym znaczeniem ${ }^{17}$, wskazuje, iż chodzi o wartości powszechne, ogólnoludzkie. Wartości uniwersalne - to nie są wartości efemeryczne, wartości przejściowe. Nie są to również wartości zrelatywizowane. Są to wartości ponadczasowe (ponadhistoryczne). Uniwersalnych wartości człowiek nie ustanawia, nie kreuje, natomiast może je poznawać. W poznaniu jednak można popełnić błąd.

Trzeba też rozważyć, czy wskazane wartości mają charakter obiektywny, czy subiektywny. Co to znaczy wartości subiektywne? Sięgnijmy do etymologii: łac. subiectivus - 'podmiotowy'; subiectum - 'podmiot'18. Subiektywizm to pogląd, według którego ludzkie poznanie i jego przedmiot są funkcją struktury psychofizycznej człowieka ${ }^{19}$. Również podstawowe znaczenia słownikowe idą w tym kierunku. W słownikach są także znaczenia filozoficzne, np. w Stowniku języka polskiego PWN pod hasłem subiektywizm czy tamy: ,stanowisko związane $\mathrm{z}$ relatywizmem teoriopoznawczym, zakładające, że przedmiot poznania nie istnieje obiektywnie, lecz jedynie subiektywnie, tj. zależnie od podmiotu (umysłu) poznającego" ${ }^{20}$. Jeśli wartości będące przedmiotem rozważań byłyby subiektywne, to by znaczyło, że są „,zależne od podmiotu poznającego"21.

\footnotetext{
${ }^{15}$ J. Rawls, Teoria sprawiedliwości, Warszawa 1994, s. 13.

${ }^{16}$ L. Garlicki, Wstęp (pkt 9), [w:] idem (red.), Konstytucja Rzeczypospolitej Polskiej...

${ }^{17}$ Por. M. Szymczak (red.), Stownik języka polskiego PWN, t. 3, Warszawa 1995, s. 561.

${ }^{18}$ Por. M. Plezia (red.), Stownik łacińsko-polski, t. V, s. 244.

${ }^{19}$ Por. H. Kiereś, Subiektywizm, [w:] Powszechna encyklopedia ..., t. 9, s. 254.

${ }^{20}$ M. Szymczak (red.), Słownik języka polskiego PWN, t. 3, s. 339.

${ }^{21}$ Por. znaczenie słowa „subiektywny”. Ibidem.
} 
Subiektywizm stoi w opozycji do obiektywizmu. Łacińskie słowo obiectivus oznacza 'przedmiotowy'22. Słownik języka polskiego PWN podaje filozoficzne znaczenie terminu obiektywizm: ,stanowisko ontologiczne lub teoriopoznawcze, zgodnie z którym przedmiot poznania istnieje poza podmiotem poznającym i niezależnie od niego, i może być przezeń poznawany w sposób adekwatny" 23 .

Tak więc ogólnie rzecz ujmując - obiektywne jest to, co jest (istnieje) niezależne od podmiotu poznającego, niezależne od świadomości, zastane (niezależne od poglądów, woli, emocji). Natomiast subiektywne oznacza podmiotowe, zależne od podmiotu (umysłu) poznającego (pojętego w sposób indywidualny lub zbiorowy), zrelatywizowane podmiotowo.

Jest oczywiste, że niepodobna w tym opracowaniu gruntownie zanalizować i uzasadnić obiektywność każdej z tych wartości. Zatem, najkrócej jak można, rozważmy to zagadnienie.

„Czym jest prawda?" - to jedno z najstarszych pytań filozoficznych. Prawda (gr. alétheia, łac. veritas, verum) w jakim znaczeniu? O jaką prawdę tu chodzi? Wydaje się, że nie chodzi o to, co dotyczy także pozostałych uniwersalnych wartości, o dokonanie konstytucyjnej charakterystyki istoty Boga (określenie przymiotów Boga), to bowiem - jak podkreśla Leszek Garlicki - wykraczałoby poza misję i kompetencje ustawy zasadniczej ${ }^{24}$. Nie chodzi zatem o prawdę w znaczeniu teologicznym. Raczej nie chodzi tu też o prawdę w sensie metafizycznym ${ }^{25}$, ani o prawdę w sensie ontycznym (ontologiczną). Należy przyjać, że idzie tu o podstawowe, klasyczne rozumienie prawdy, a zatem o prawdę w ujęciu poznawczym (o epistemologiczny wymiar prawdy).

Prawda jest uzgodnieniem intelektualnego poznania i rzeczy (veritas est adaequatio intellectus et rei). Tak więc chodzi o zgodność treści poznania z jego przedmiotem - uzgodnienie sądu z rzeczywistością. Tak rozumiana prawda jest niestopniowalna (stopniowalne jest natomiast poznanie), niezmienna, niezależna od podmiotu poznającego (uznającego coś za prawdę) i zewnętrznych okoliczności ${ }^{26}$. Prawda jest dorównywaniem (treści) myśli temu, do czego się ona odnosi ${ }^{27}$. Można powiedzieć, że prawda jest obiektywnym (niezależnym od podmiotu) obrazem rzeczywistości taką, jaka ona jest. W Słowniku języka polskiego PWN czytamy, że obiektywność prawdy to „cecha sądu (twierdzenia) prawdziwego, polegająca na trafnym, adekwatnym

${ }^{22}$ Por. J. Sondel, Słownik tacińsko-polski dla prawników i historyków, Kraków 2009, s. 672.

${ }^{23}$ M. Szymczak (red.), Stownik języka polskiego PWN, t. 2, s. 391.

${ }^{24}$ Por. L. Garlicki, Wstęp (pkt 10), [w:] idem (red.), Konstytucja Rzeczypospolitej Polskiej...

${ }^{25}$ Prawda w sensie metafizycznym - powszechna właściwość bytów realizujących w swym istnieniu zamysł (ideę) Stwórcy (świat natury) lub twórcy (świat kultury). Szerzej: A. Maryniarczyk, Prawda, [w:] Powszechna encyklopedia filozofii, t. 8, Lublin 2007, s. 458, 461-462.

${ }^{26}$ Por. A. B. Stępien, Wstęp do filozofii, Lublin 2007, s. 137.

${ }^{27}$ Ibidem, s. 138. 
odzwierciedleniu rzeczywistego stanu rzeczy, o którym sąd ten orzeka"28. Prawda, rzecz jasna, nie jest stwarzana przez intelekt, lecz poznawana, rozpoznawana.

Precyzując nieco tę wartość konstytucyjną, trzeba powiedzieć, że chodzi o prawdę o rzeczywistości, w tym prawdę o człowieku, której odrzucenie jest błędem intelektualnym i moralnym. Przy formułowaniu (tworzeniu) norm należy koniecznie liczyć się z obiektywną rzeczywistością, uwzględniać ją. Przystępując do tworzenia prawa, trzeba mieć pewną wiedzę o rzeczywistości, w tym wiedzę o bytowym wymiarze osoby ludzkiej. Podkreślić też trzeba, że Trybunał Konstytucyjny w wyroku z 12 września 2005 r. (SK 13/05, OTK ZU 2005, Ser. A, nr 8, poz. 91) przyjął, że prawda jest pojęciem normatywnym, stwierdzając: „Ustrojodawca w preambule Konstytucji uznaje prawdę za wartość uniwersalną, na której opiera się ustrój Rzeczypospolitej”.

Jeśli chodzi o dobro (gr. agathón, łac. bonum), w filozofii odróżnia się dobro w sensie metafizycznym ${ }^{29}$ (sposób bytowania rzeczy), dobro moralne, dobro w sensie ekonomicznym (użyteczność rzeczy), a także estetycznym (doskonałość rzeczy). Trudno jednoznacznie stwierdzić, czy w Konstytucji chodzi o dobro w sensie metafizycznym, czy o dobro w sensie moralnym. Mniej zawiłości implikować będzie przyjęcie, że chodzi o dobro w sensie moralnym. Jednak trzeba mieć na uwadze, że w filozofii twierdzono i twierdzi się nadal, iż podstawą wszelkiego rozumienia dobra jest dobro w sensie metafizycznym ${ }^{30}$.

Jak można uzasadnić obiektywność dobra? Odwołując się do argumentacji Władysława Tatarkiewicza, można wskazać trzy możliwości: 1) dobra nie ma (nie ma dobra i zła); 2) dobro jest subiektywne; 3) dobro jest obiektywne. Pierwsze ujęcie jest oczywiście „niedorzeczne”31. Pozostają zatem dwie możliwości: dobro jest albo subiektywne, albo obiektywne. W odniesieniu do powyższego W. Tatarkiewicz konstatuje:

Jeśli subiektywizm jest teorią fałszywą, to obiektywizm jest prawdziwą. Innego dowodu prawdziwości obiektywizmu niż dowód fałszywości subiektywizmu nie potrzeba. Dowodząc bowiem fałszywości subiektywizmu, dowodzę, że dobro i zło nie są zależne od podmiotu, a przez to samo dowodzę prawdziwości obiektywizmu².

${ }^{28}$ M. Szymczak (red.), Słownik języka polskiego PWN, t. 2, s. 391.

${ }^{29}$ Dobro w sensie metafizycznym - powszechna (transcendentalna) właściwość, ukazująca każdy byt jako pochodny od woli twórcy lub Stwórcy i bytujący jako cel wszelkiego dążenia A. Maryniarczyk, Dobro, [w:] Powszechna encyklopedia filozofii, t. 2, Lublin 2001, s. 614.

${ }^{30}$ Ibidem.

${ }^{31}$ Pomija je także W. Tatarkiewicz.

${ }^{32}$ W. Tatarkiewicz, O bezwzględności dobra, [w:] P. J. Smoczyński (red.), Dobro i oczywistośśc, Lublin 1989, s. 79. 
Jest to zgodne z wcześniejszymi rozważaniami. Podsumujmy zatem: gdyby dobro było subiektywne, to by znaczyło, że jest zależne od podmiotu. A przecież tak nie jest. Dobro jako wartość uniwersalna jest niezależne od czyichś ocen, przeżyć, poglądów, reakcji emocjonalnych. Dla uniwersalnych wartości jest obojętne, kto je uznaje, czy wszyscy je uznają. Jeśli ktoś twierdzi, że $X$ jest dobre, to nie znaczy, że dobro istnieje w zależności od tego podmiotu. Konsekwentnie trzeba przyjąć, iż człowiek nie może uczynić siebie miarą dobra istniejącego, że istnieje - i nieistniejącego, że nie istnieje, skoro Bóg, jak stanowi Konstytucja, jest źródłem dobra. Człowiek nie może postawić się ponad dobrem. Skoro Bóg jest źródłem dobra, to człowiek nie może traktować tej wartości jako subiektywnej. Przecież to nie od jakiegoś człowieka, ani też od państwa (i nie od umowy społecznej) zależy istnienie dobra. Dobro jako wartość uniwersalna nie może bazować na subiektywnych odczuciach ludzkich.

Przejdźmy do piękna. Piękno - gr. kalós, łac. pulchrum. Trudno odpowiedzieć na pytanie, w jakim znaczeniu ustrojodawca rozumiał piękno. W ujęciu konstytucyjnym piękno nie powinno być jednak redukowane do estetyki. Jeśli piękno rozumiemy klasycznie, to jest ono pojmowane szerzej - starożytni Grecy nie wysuwali na plan pierwszy sztuki, lecz rzeczywistość (kosmos) i moralność ${ }^{33}$. U Arystotelesa słowo kalós, właśnie w znaczeniu moralnym, pojawia się niejednokrotnie. Pisze on o „dokonywaniu czynów moralnie pięknych”, ,,moralnie pięknym postępowaniu”34. Myśliciele starożytni w małym stopniu ,piękno zaledwie odróżniali od dobra i doskonałości”. Warto tutaj zacytować fragment Uczty Platona, który pisze:

[...] piękno wieczne, które nie powstaje i nie ginie, i nie rozwija się ani nie więdnie, ani nie jest $\mathrm{z}$ jednej strony piękne, a z drugiej szpetne, ani raz tylko takie, a drugi raz odmienne, ani takie w porównaniu z czymkolwiek, a z czym innym inne, ani też dla jednego piękne, a dla drugiego szpetne [...] piękno samo w sobie niezmienne i wieczne, a wszystkie inne przedmioty piękne uczestniczą w nim jakoś w ten sposób, że podczas gdy same powstają i giną, ono ani się pełniejszym nie staje, ani uboższym, ani go żadna w ogóle zmiana nie dotyka [...], na tym szczeblu dopiero życie jest coś warte: wtedy, gdy człowiek piękno samo w sobie ogląda ${ }^{35}$.

Myśliciele klasycznej Grecji „za najprawdziwsze piękno mieli właśnie duchowe, moralne piękno charakteru, umysłowe piękno myśli”’36. Współcześnie także niekiedy podkreśla się duchowy charakter piękna ${ }^{37}$. I tutaj należy

${ }^{33}$ Dla Greków słowo kalós skierowane było głównie na dobro moralne.

${ }^{34}$ Arystoteles, Etyka nikomachejska, 1120a. Por. także: 1127a, 1121a, 1179b. W innym znaczeniu w Metafizyce Arystoteles pisze, że piękno znajduje się także w bytach nieruchomych.

${ }^{35}$ Platon, Uczta, 210E-211D. To, co w tym fragmencie Uczty Platon nazywał ideą piękna, mógł również - jak zauważa W. Tatarkiewicz - nazwać ideą dobra, nie chodziło bowiem o piękno widzialne i słyszalne. Por. W. Tatarkiewicz, Piękno. Dzieje pojęcia, [w:] idem, O filozofii i sztuce, Warszawa 1986, s. 176.

${ }^{36}$ W. Tatarkiewicz, Dzieje sześciu pojęć..., s. 176.

${ }^{37}$ Por. H. Kiereś, Filozofia sztuki, [w:] Powszechna encyklopedia filozofii, t. 3, Lublin 2002, s. 520. 
zauważyć, iż szersze pojmowanie piękna zachowało aktualność - w Słowniku języka polskiego PWN pod hasłem piękno w drugim znaczeniu czytamy: „wysoka wartość moralna"38.

A jeśli nawet ktoś by przyjmował, że piękno w Konstytucji rozumiane jest jako wartość estetyczna, to jeszcze nie niweczyłoby sensowności rozważań o obiektywności piękna i jego poznawalności. Od dawna przedmiotem sporu jest to, czy piękno jako wartość estetyczna jest obiektywne czy subiektywne. Najogólniej rzecz biorąc, chodzi tu o to, czy piękno jest własnością rzeczy, czy też tylko ludzką reakcją na rzecz. Już przed wiekami pytano: „czy dlatego coś jest piękne, że się podoba, czy też dlatego się podoba, że jest piękne”. Klasyczna odpowiedź będąca wyrazem obiektywizmu brzmiała: „rzecz dlatego się podoba, ponieważ jest piękna”. Przez wieki podawano różne obiektywne kryteria piękna. Podsumowaniem dokonań tradycji jest ujęcie św. Tomasza z Akwinu, zgodnie z którym:

Piękno wymaga spełnienia trzech warunków: pierwszym jest pełnia, czyli doskonałość rzeczy, to bowiem, co posiada braki, jest brzydkie; drugi warunek to właściwa proporcja czyli harmonia; trzecim zaś jest blask ${ }^{39}$.

Od starożytności aż do XVII w. dominowało przekonanie o obiektywności piękna. Spór ten trwa nadal. Przykładowo, w jednym z nurtów estetyki obiektywistycznej przyjmuje się, że „prawdziwa sztuka i prawdziwe piękno opierają się na niezmiennych regułach-normach" ${ }^{\prime 40}$.

Czy można współcześnie stanowczo stwierdzić, że piękno (w tym także jako wartość estetyczna) w sensie obiektywnym nie istnieje? Stanowisko takie, jak się wydaje, w kontekście piękna jako wartości konstytucyjnej byłoby nieuzasadnione. A jeśli chodzi o poznawalność piękna, byłoby aprioryzmem twierdzenie o jego niepoznawalności i odrzucenie tezy kognitywnej. Piękno z pewnością można odnosić do aktów poznania i, co istotne, nie tylko poznania zmysłowego - co by zachodziło zasadniczo, gdyby piękno sprowadzić do kontekstu estetycznego. Gdy pojmujemy piękno szerzej, oczywiste jest, iż chodzi o poznanie intelektualne (poznanie umysłowe). Nieprzekonujące, rzecz jasna, jest odnoszenie piękna tylko do stanów emocjonalnych, przeżyć, uczuć. Warto podkreślić, że estetyka jako odrębna nauka powstała dopiero w XVIII w., a jej twórca, Aleksander Baumgarten, zdefiniował piękno jako „doskonałość poznania zmysłowego" (perfectio cognitionis sensitivae qua talis) ${ }^{41}$.

${ }^{38}$ M. Szymczak (red.), Stownik języka polskiego PWN, t. 2, s. 635.

${ }^{39}$ Św. Tomasz z Akwinu, Summa theologiae, I, q. 39, a. 8. Por. W. Tatarkiewicz, Historia estetyki, t. 2: Estetyka średniowiecza, Warszawa 1989, s. 225-227.

${ }^{40}$ Por. H. Kiereś, Estetyka, [w:] Powszechna encyklopedia ..., t. 3, s. 226.

${ }^{41}$ A. Baumgarten nazwał dział filozofii badający poznanie piękna grecko-łacińskim zwrotem cognitio aesthetica. Szerzej: W. Tatarkiewicz, Przeżycie estetyczne. Dzieje pojęcia, [w:] idem, Dzieje sześciu pojęć..., s. 362. 
Można też za myślicielami starożytnej Grecji utożsamiać dobro z pięknem (tzw. kalokagathía), bądź przyjąć, że piękno jest syntezą prawdy i dobra (É. Gilson, M. A. Krąpiec).

Wskazane powyżej uniwersalne wartości preambuły nie tworzą jeszcze pełnej metaaksjologii Konstytucji. Fundamentalne znaczenie ma kategoria godności człowieka.

Wyrażona w art. 30 Konstytucji $\mathrm{RP}^{42}$ zasada przyrodzonej godności akcentuje ponadpozytywną, a więc nadrzędną wobec samej Konstytucji, istotę godności człowieka. Trzeba zgodzić się z Leszkiem Garlickim, który pisze: „źródłem godności człowieka jest prawo naturalne, a nie prawo stanowione”43. Godność jest pierwotna i niezależna od regulacji prawa pozytywnego, nie jest zależna od woli prawodawcy, nie jest nadawana ani nie może być odebrana żadnym działaniem ludzkim, działaniem władz publicznych. Przymiotem godności jest jej nienaruszalność. Godność człowieka jest podstawą i źródłem wszystkich praw człowieka $\mathrm{i}$ ich ochrony. Jest rzeczywistą podstawą praw oraz ich uzasadnieniem. I to źródło wolności i praw człowieka i obywatela ma zasadniczą obiektywność oraz niedysponowalność. Z godności wypływają normy niezbywalne, niemodyfikowalne przez jakikolwiek ustrój czy prawodawstwo.

Godność, o której mówi Konstytucja, jak pisze Krystian Complak, można określić: ,[...] jako człowieczeństwo czy świętość osoby ludzkiej. Godność ta istnieje niezależnie od subiektywnych wyobrażeń jednostki o sobie. Jest ona nierozerwalnie związana z każdą istotą ludzką" ${ }^{4}$. Przyrodzona i niezbywalna godność jest niezależna od świadomości i przeżyć człowieka.

Polski Trybunał Konstytucyjny wielokrotnie nawiązywał do zasady godności człowieka, akcentując m.in., że jest to: ,[...] wartość transcendentna, pierwotna wobec innych praw i wolności człowieka (dla których jest źródłem), przyrodzona i niezbywalna [...]" $]^{\prime 4}$, że stanowi ona ,[...] fundament całego porządku prawnego w państwie" ${ }^{" 46}$; akcentował również bezwzględny zakaz jej naruszania ${ }^{47}$. Podkreślał też, iż ,[...] jest to jedyne prawo, wobec którego nie byłoby możliwe zastosowanie zasady proporcjonalności"48. W uzasadnieniu wyroku z 15 października

${ }^{42}$ Art. 30 brzmi: „Przyrodzona i niezbywalna godność człowieka stanowi źródło wolności i praw człowieka i obywatela. Jest ona nienaruszalna, a jej poszanowanie i ochrona jest obowiązkiem władz publicznych”. Także preambuła „wzywa” stosujących Konstytucję, ,aby czynili to, dbając o zachowanie przyrodzonej godności człowieka".

${ }^{43}$ L. Garlicki, Polskie prawo konstytucyjne. Zarys wyktadu, Warszawa 2010, s. 91.

${ }^{44}$ K. Complak, Godność człowieka, [w:] W. Skrzydło, S. Grabowska, R. Grabowski (ed.), Konstytucja Rzeczypospolitej Polskiej. Komentarz encyklopedyczny, Warszawa 2009, s. 165.

${ }^{45}$ Wyrok TK z dnia 5 marca 2003 r. (K 7/01, OTK ZU 2003, Ser. A, nr 3, poz. 19).

${ }^{46}$ Wyrok TK z dnia 4 kwietnia 2001 r. (K 11/00, OTK ZU 2001, nr 3, poz. 54).

${ }^{47}$ Ibidem.

${ }^{48}$ Wyrok TK z dnia 5 marca 2003 r. (K 7/01, OTK ZU 2003, Ser. A, nr 3, poz. 19). 
2002 r. (SK 6/02, OTK ZU 2002, Ser. A, nr 5, poz. 65) stwierdził, że „[...] godność ludzka może być traktowana jako samoistny wzorzec konstytucyjny, także w wypadku skargi konstytucyjnej”; podkreślił również, że:

Godność człowieka, o której mowa w art. 30 Konstytucji, pełni w porządku konstytucyjnym kilka funkcji: łącznika między Konstytucją (akt prawa pozytywnego) a porządkiem prawnonaturalnym; determinanty interpretacji i stosowania Konstytucji; wyznacznika systemu i zakresu poszczególnych praw i wolności [...].

Konsekwencją art. 30 jest to, że godność osoby ludzkiej stanowi, iż prawa człowieka nie wynikają z woli państwa, z pozytywnego aktu stanowienia ${ }^{49}$, lecz mają charakter przyrodzony. Zatem należy przypisać im cechę prawnonaturalności. I można powiedzieć, że wolności i prawa człowieka jako powiązane, wywodzone z przyrodzonej i niezbywalnej godności (godność jest ich źródłem), są też obiektywnie ugruntowane. W konkluzji należy stwierdzić, że godność jest kategorią obiektywną. Jest to wartość absolutna, stała i niezniszczalna. Godność należałoby rozumieć jako ,prawo do praw”.

Warto dodać, że w wyroku z 23 marca 1999 r. (K 2/98, OTK ZU 1999, nr 3, poz. 38) Trybunał Konstytucyjny wskazał, iż:

Konstytucja w całokształcie swych postanowień daje wyraz pewnemu obiektywnemu systemowi wartości, którego urzeczywistnianiu służyć powinien proces interpretacji i stosowania poszczególnych przepisów konstytucyjnych. Dla określenia tego systemu wartości centralną rolę odgrywają postanowienia o prawach i wolnościach jednostki, usytuowane przede wszystkim w rozdziale II Konstytucji. Wśród tych postanowień centralne z kolei miejsce zajmuje zasada przyrodzonej i niezbywalnej godności człowieka.

Podstawowe znaczenie dla metaaksjologii Konstytucji mają ponadto - stanowiące rozwinięcie wartości uniwersalnych wskazanych we wstępie - zasada dobra wspólnego (art. 1 Konstytucji) i zasady sprawiedliwości społecznej (art. 2 Konstytucji).

Dotychczas zasada dobra wspólnego nie jest dostatecznie dostrzegana i wykorzystywana przez orzecznictwo sądowe i sądowokonstytucyjne. Zasada „dobra wspólnego” (a nie „wspólnego dobra”) ${ }^{50}$ wyraża ideę państwa służebnego

${ }^{49}$ J. Mikołajewicz i M. Smolak podkreślają, że są takie prawa, które nie są kreowane (konstytuowane) przepisami konstytucji. Przykładem może być prawo człowieka do życia. „Faktowi obowiązywania takich praw nie sposób zaprzeczyć”, a też „nie sposób utrzymywać, że źródłem ich jest pozytywny akt stanowienia czy ogólnie arbitralna wola ludzka". To przysparza pozytywistom, jak podkreślają autorzy, szczególnego rodzaju trudność. I dalej konstatują: ,„[...] twierdzenie o niezależnym obowiązywaniu tych praw unaocznia swoistą paradoksalność pozytywizmu" - J. Mikołajewicz, M. Smolak, Zasada demokratycznego państwa prawnego w aksjologii Konstytucji Rzeczypospolitej Polskiej, [w:] S. Wronkowska (red.), Zasada demokratycznego państwa prawnego w Konstytucji RP, Warszawa 2006, s. 91-92.

${ }^{50}$ Zmiana szyku wyrazów - a więc nie tak, jak przyjęto w Konstytucji z 1935 r. „wspólnym dobrem” (art. 1 ust. 1 Konstytucji kwietniowej z 1935 r.: „Państwo polskie jest wspólnym dobrem 
wobec swych obywateli. Dobro wspólne nie jest przeciwstawne dobru cząstkowemu - osobowemu. Dobro człowieka jest podstawowym wyznacznikiem dobra wspólnego. Nakazem dobra wspólnego jest ochrona praw człowieka. Zakłada ono poszanowanie każdej osoby jako takiej. Dobro wspólne to dobro człowieka i jednocześnie dobro wspólnoty.

Można mówić o prawnonaturalnym charakterze dobra wspólnego, a pojęcie to ma długą tradycję, która wiąże się znacząco z myślą św. Tomasza z Akwinu i ma od dawna ukształtowane znaczenie w chrześcijańskiej nauce społecznej. Do takiego właśnie uzasadnienia znaczenia tego pojęcia, jak podkreśla się w literaturze, odwoływano się w toku prac przygotowawczych, których efektem było wprowadzenie tego pojęcia do art. 1 Konstytucji RP ${ }^{51}$. Marek Piechowiak w pracy pt. Dobro wspólne jako fundament polskiego porzqdku konstytucyjnego dowodzi, że ustrojodawca uznał koncepcję obiektywnego ugruntowania dobra wspólnego; uzasadnia też prawnonaturalny charakter tej wartości ${ }^{52}$.

Swoistą konkretyzacją sprawiedliwości (gr. dikaiosyne, łac. iustitia) jest sprawiedliwość społeczna. Refleksję klasyczną nad sprawiedliwością, do której przynależy myśl Platona i Arystotelesa, charakteryzuje uznanie obiektywnego ugruntowania tego, co sprawiedliwe. Sprawiedliwość społeczna nie odnosi się do jednostkowych poglądów, odczuć i ocen, lecz do szeroko rozumianych stosunków społecznych, struktur społecznych. Sprawiedliwość ta jest uspołeczniona, odnosi się do relacji między grupami społecznymi oraz relacji między nimi a państwem. Jest to zatem sprawiedliwość zobiektywizowana. Warto podkreślić, że Trybunał Konstytucyjny w wyroku z 6 lipca 1999 r. (P2/99, OTK ZU 1999, nr 5, poz. 103), odwołując się do konstytucyjnej zasady sprawiedliwości społecznej, podkreśla, by sprawiedliwość „była wolna od subiektywnych interesów i subiektywnej postaci".

Wyrażony w art. 2 Konstytucji RP obowiązek (nakaz) urzeczywistniania zasad sprawiedliwości społecznej, skierowany do organów państwa, należy rozumieć jako związany z uniwersalną wartością - sprawiedliwością wyrażoną w preambule Konstytucji. Konsekwentnie, nie powinno się a priori odrzucać ponadpozytywnego, prawnonaturalnego, czy może jeszcze wyższego uzasadnienia sprawiedliwości, skoro Konstytucja mówi, iż Bóg jest źródłem sprawiedliwości.

wszystkich obywateli”), lecz „dobrem wspólnym” (art. 1 Konstytucji z 1997 r.: „Rzeczpospolita Polska jest dobrem wspólnym wszystkich obywateli”) - wyraża jakościową zmianę tej kategorii pojęciowej. Por. W. Sokolewicz, Rozdziat I, ,Rzeczpospolita”, art. 1, pkt 1, [w:] L. Garlicki (red.), Konstytucja Rzeczypospolitej Polskiej... Por. także: M. Piechowiak, Aksjologiczne podstawy..., s. 112.

${ }^{51}$ Por. M. Piechowiak, Prawnonaturalny charakter klauzuli dobra wspólnego, [w:] A. Choduń, S. Czepita, (red.), W poszukiwaniu dobra wspólnego. Księga jubileuszowa Profesora Macieja Zielińskiego, Szczecin 2010, s. 603-604.

${ }^{52}$ Por. M. Piechowiak, Dobro wspólne jako fundament polskiego porzadku konstytucyjnego, Warszawa 2012, s. 316-318, 436-437. 
I właśnie w szczególności te dwie zasady, wraz z zasadą przyrodzonej i niezbywalnej godności człowieka oraz wskazanymi w preambule uniwersalnymi wartościami, tworzą metaaksjologię Konstytucji RP. I trzeba dodać, że ta metaaksjologia jest spójna. Konsekwentnie należy przyjąć, iż te rozstrzygnięcia metaaksjologiczne pozostają w opozycji do relatywizmu aksjologicznego, a także do subiektywizmu aksjologicznego i sceptycyzmu etycznego.

2. W pracach z zakresu teorii prawa wartości są bardzo często wiązane z ocenami. Przyjmuje się, że „wartościowy to tyle, co oceniany”53, zakłada się, iż wartości to „refleks ocen przeżywanych w psychice poszczególnych jednostek" ${ }^{4}$, twierdzi się, że „wartości nie istnieją bez określonych stanów świadomości (psychiki) określonych ludzi i poza tymi stanami”" wym znaczeniu, jak się przyjmuje, oznacza „przeżycie aprobaty czy dezaprobaty jakiegoś stanu rzeczy lub zdarzenia" ${ }^{56}$, ,przeżycia polegające na emocjonalnym ustosunkowaniu się do jakichś faktycznie występujących czy też tylko wyobrażanych sobie stanów rzeczy czy zdarzeń, a więc na aprobowaniu lub dezaprobowaniu czegos' " 57 , „ocena w typowym przypadku posługiwania się nią jest wyrażeniem przeżyć wartościowania (oceniania) określonego podmiotu"58.

Tak więc $\mathrm{w}$ teorii prawa często przyjmuje się, że wartościowanie, ocenianie, oparte jest na emocjach, przeżyciach, a nie na rozumie, poznaniu. Takie podejście, rzecz jasna, jest przejawem nonkognitywizmu. Tak więc wypowiedzi pozaopisowe nie mają wartości poznawczej, nie są ani prawdziwe, ani fałszywe. Akognitywizm głosi, że wartość jest wyznaczana przez niepoznawczy - emocjonalny lub wolitywny - stosunek podmiotu wartościującego względem przedmiotu wartościowego. Oczywiście, dominującym stanowiskiem nonkognitywistycznym jest emotywizm, będący mocną postacią subiektywizmu etycznego.

53 J. Wróblewski, Wartości a decyzja sqdowa, Wrocław-Warszawa-Kraków-Gdańsk 1973, s. 44.

${ }^{54}$ Z. Ziembiński, Problemy podstawowe prawoznawstwa, Warszawa 1980, s. 102. Jak pisze dalej Z. Ziembiński, na wartości możemy patrzeć również ,jako na wyabstrahowany obiekt ocen kształtowanych w określonym środowisku społecznym, jako na odniesienie znaczeniowe wypowiedzi oceniających, ale nie na jakiś odrębny rodzaj «bytów»" - ibidem.

${ }^{55}$ K. Pałecki, O aksjologicznych zmianach w prawie, [w:] L. Leszczyński (red.), Zmiany społeczne a zmiany w prawie. Aksjologia, konstytucja, integracja europejska, Lublin 1999, s. 15-16. Autor pisze, że: ,[...] wartości są emocjonalnymi projekcjami względem dowolnego obiektu lub stanu rzeczy. Są zatem «wytworem» emocjonalnej relacji zachodzącej pomiędzy psychiką (świadomością) określonych ludzi a obiektami należącymi do natury lub/i kultury. Obiekty naturalne lub/i ludzkie produkty materialne i niematerialne stają się wartościami zawsze w odczuciu «kogoś» i nigdy «w ogóle», zawsze w jakimś stopniu i nigdy idealnie, zawsze w określonym czasie i miejscu, nigdy ponadczasowo i całkowicie uniwersalnie" - ibidem.

${ }^{56}$ Z. Ziembiński, Wartości konstytucyjne. Zarys problematyki, Warszawa 1993, s. 17.

${ }^{57}$ M. Zieliński, Z. Ziembiński, Uzasadnianie twierdzeń ocen i norm w prawoznawstwie, Warszawa 1988, s. 40-41.

${ }^{58}$ J. Wróblewski, op. cit., s. 43. 
Warto postawić pytanie, czy można i jak można mówić o reakcjach emocjonalnych racjonalnego prawodawcy. Chodzi tu m.in. o problem racjonalności emocji. Zasadnicze jest też pytanie, czy emocje mogą być uniwersalne. Podkreślić tu należy, iż emocja jest subiektywnym stanem psychicznym ${ }^{59}$, a wiele z nich cechuje spontaniczność. Oczywiście, emocje mogą wpływać na czynności poznawcze - moga je modyfikować, niekiedy deformująco.

3. Należy wyraźnie zaznaczyć, że uznanie w Konstytucji elementów prawnonaturalnych wiąże się z uznaniem kognitywizmu, w jakimś chociażby częściowym, ale niezmiernie istotnym zakresie (już przecież wyrażony przez prawodawcę ontologiczny status wolności i praw człowieka koresponduje wyraźnie $\mathrm{z}$ kognitywizmem). Są w systemie prawnym bardzo istotne elementy, które czerpią swe uzasadnienia z kognitywizmu.

I skoro ustrojodawca $\mathrm{w}$ Konstytucji uznaje elementy prawnonaturalne - co jest niepodważalne - to koncepcja ocen i wartości zakładająca, iż oceny nie mają statusu poznawczego, a zatem nie mogą być prawdziwe lub fałszywe, wymaga przemyślenia i odpowiednich modyfikacji. Przyjęcie założenia, że oceny nie mają kwalifikacji prawdziwościowej budzi poważne wątpliwości wobec uznania w Konstytucji elementów prawnonaturalnych, i to w takiej wersji, dla której kognitywizm jest zasadniczy. Istnieją zatem takie wartości konstytucyjne, których źródłem nie jest państwo, ani nawet suweren - Naród, ani społeczeństwo, ani żadna umowa społeczna czy też arbitralna wola ludzka. Są więc wartości niezależne od indywidualnych poglądów, odczuć, reakcji emocjonalnych i postaw.

Jeśli chodzi o oceny - niektóre mogą być prawdziwe lub fałszywe. Mogą mieć charakter sądów, mówić coś o rzeczywistości. Są więc oceny mające status poznawczy. A tym, co decyduje o ich wartości logicznej, jest rzeczywistość niezależna od podmiotów. Prawdziwość lub fałszywość takich ocen nie jest zrelatywizowana do preferencji, uczuć podmiotu (lub zbiorowości podmiotów). Tak więc niektóre oceny są rezultatem poznania rzeczywistości normatywnej, niebędącej wynikiem działań człowieka. Dość rozpowszechnione w prawoznawstwie rozumienie ocen wydaje się zatem specyficzne, na co wskazywałyby także słownikowe znaczenia tego słowa: „ocena to sąd o wartości czegoś”, ${ }^{\circ}$, „sąd wartościujący"61.

Trzeba też podkreślić, że negacja obiektywnie istniejących, uniwersalnych wartości, będących stałym punktem odniesienia, jest przejawem relatywizmu aksjologicznego (względności wartości), w którym twierdzi się, że wartością jest to, co człowiek za wartość uznaje, przeżywa.

59 J. Strelau (red.), Psychologia. Podręcznik akademicki, t. 2: Psychologia ogólna, Gdańsk 2007, s. 322.

${ }^{60}$ M. Szymczak (red.), Słownik języka polskiego PWN, t. 2, s. 416.

${ }^{61}$ H. Zgółkowa (red.), Praktyczny słownik współczesnej polszczyzny, t. 25, Poznań 2000, s. 176. Por. także: B. Dunaj (red.), Słownik współczesnego języka polskiego, t. 1, Warszawa 1996, s. 642 . 
Skoro Konstytucja przyjmuje istnienie uniwersalnych wartości; skoro otwiera się na prawo naturalne, a tym samym na wartości obiektywne (obiektywnie ugruntowane), to takie rozstrzygnięcia metaaksjologiczne - podkreślmy raz jeszcze - pozostają w sprzeczności z koncepcjami relatywistycznymi, subiektywistycznymi $^{62}$, nie godzą się też ze sceptycyzmem aksjologicznym ${ }^{63}$. Sprzeciwiają się również „,czystemu” konwencjonalizmowi zakładającemu, że wartości są sprawą umowy, konwencji.

Podkreślmy na koniec, że zagadnienia metaaksjologii Konstytucji ${ }^{64}$ są niezmiernie istotne zarówno dla procesów tworzenia prawa, jego stosowania, jak i wykładni prawa. I jeszcze jedna uwaga: wartości wskazane w Konstytucji prawda, sprawiedliwość, dobro, piękno i godność człowieka - istnieją niezależnie od ich konstytucyjnego ujęcia, zatem gdyby Konstytucja nic o nich nie mówiła, nie znaczyłoby to, że ich nie ma (w sensie ich istnienia).

${ }^{62}$ Ogólnie rzecz ujmując, chodzi o subiektywizm aksjologiczny, który głosi, że to podmiot nadaje wartość obiektom lub stanom rzeczy. Wartości zatem nie są obiektywne, lecz subiektywne.

${ }^{63}$ Sceptycyzm aksjologiczny zakłada, że o wartościach nie można powiedzieć nic pewnego (dobra nie sposób poznać).

${ }^{64}$ Art. 8 ust. 1 Konstytucji RP stanowi, że: „Konstytucja jest najwyższym prawem Rzeczypospolitej Polskiej”. Natomiast w ust. 2 tego artykułu wprowadzono zasadę bezpośredniego stosowania Konstytucji RP, chyba że Konstytucja stanowi inaczej. 